\title{
THE BUMBLEBEE HUMMINGBIRDS (ATTHIS HELOISA) OF RAMSEY CANYON REVISITED
}

\author{
CHRISTOPHER W. SWARTH, 4086 Lakeview Dr., Mariposa, California 95338; \\ cswarth10@gmail.com
}

ABSTRACT: The provenance of the two specimens constituting the only evidence of the occurrence of the Bumblebee Hummingbird in the United States has been questioned. But their origin in or near Ramsey Canyon, Arizona, in 1896 is confirmed from the journal of Harry S. Swarth, one of the four collectors who mounted an expedition to the Huachuca Mountains that year. In his journal, Swarth mentioned them as unidentified hummingbirds, one collected in Miller Canyon on 29 June 1896, the other in Brown's Canyon, a side canyon of Ramsey Canyon, the following day.

The Bumblebee Hummingbird (Atthis heloisa) occupies a singular place in the history of Arizona ornithology. The only United States record for this very small hummingbird is based on two specimens collected in 1896 at Ramsey Canyon, in the Huachuca Mountains of southern Arizona. An adult female skin (USNM 153886) is held in the collection at the U.S. National Museum of Natural History, Smithsonian Institution (Figure 1), and an immature female (MVZ 10299) is in the Museum of Vertebrate Zoology at the University of California, Berkeley (Figure 2). Harry Rising collected the birds and companion William B. Judson prepared them as museum specimens; both were young ornithologists on a collecting expedition to Ramsey Canyon. The tag attached to each specimen bears the date "July 2, 1896" and the name W. B. Judson.

Robert Ridgway (1898) described the Ramsey Canyon specimens as a new species of Atthis (A. morcomi), and later Harry S. Swarth gave details on their acquisition in two publications on Arizona birds (Swarth 1904, 1914). In 1910, these records were included in the third edition of the American Ornithologists' Union's checklist of North American birds. Their identity is not disputed. However, questions about the authenticity or provenance of these records have arisen because the Bumblebee Hummingbird has not been sighted in the United States since 1896 (Zyskowski et al. 1998, Dunn and Alderfer 2017).

Could Rising or Judson have collected the birds in Mexico or acquired

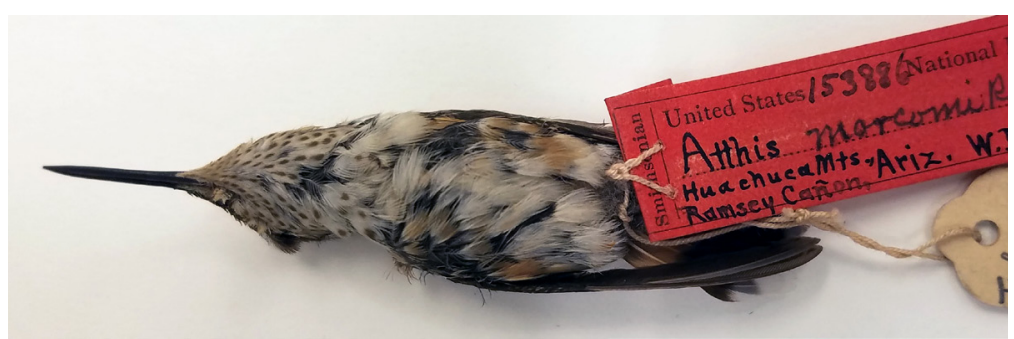

Figure 1. Adult female Bumblebee Hummingbird (Atthis heloisa) in the collection at the U.S. National Museum.

Photo by Christopher Milensky 
them from someone who had? The current northern extent of the Bumblebee Hummingbird's range in Mexico is in the central Sierra Madre Occidental, southwestern Chihuahua (Howell and Webb 1995, Arizmendi et al. 2013). Could the specimens or their tags have become mixed up in the field with other hummingbird specimens or back in Los Angeles after Rising and Judson returned from the expedition? Perhaps specimen tags were accidentally switched when the birds were accessioned into museum collections. The field journal kept by Swarth, then a 17-year old companion with Rising and Judson in Ramsey Canyon, sheds new light on these records.

The lack of Bumblebee Hummingbird sightings in the U.S. over the past 120 years may seem surprising, especially considering that Ramsey and nearby mountain canyons in southern Arizona have been extensively explored by legions of birders over the past half century. Howell (2002) emphasized that this hummingbird could be easily overlooked because it is generally silent and often feeds and perches "inside flower banks." Nevertheless, if Bumblebee Hummingbirds inhabited these canyons today or in recent decades, it is reasonable to expect that someone would have observed one.

\section{HISTORICAL BACKGROUND}

On 29 February 1896, Judson, Rising, O. W. Howard, and Harry S. Swarth departed Los Angeles on a journey on foot, horseback, and by wagon to the Huachuca Mountains. The men, all in their late teens, were active southern California birders. Their expedition was inspired by Major Charles Bendire, a U.S. Army officer and well-known oologist recognized for the large egg collection he had donated to the Smithsonian Institution. Bendire's familiarity with the birdlife of Arizona and New Mexico, acquired while serving in that region, led him to correspond with George Frean Morcom of Los Angeles and to suggest the Huachucas as a favorable location for study. Morcom was known for financing bird-collecting trips in California, and at this time he was Swarth's mentor. He agreed to provide the financial support for the Ramsey Canyon expedition. This was the second organized ornithological expedition to Arizona, coming only a few years after C. Hart Merriam's biological survey of the San Francisco Mountain region in 1889 (Merriam 1890). After two months of travel, according to Swarth, the group established camp on 25 April, "up Ramsey Canyon, about a mile and a half, as far as the wagon road went." For three months they explored and collected birds in Ramsey, Brown, Miller, and Carr canyons, with occasional trips onto the desert plain to the east.

Hummingbirds are abundant and diverse in Ramsey Canyon. In addition to the Bumblebee Hummingbirds, the group collected 42 specimens and observed 9 species: the Rivoli's (Eugenes fulgens), Blue-throated (Lampornis clemenciae), Black-chinned (Archilochus alexandri), Costa's (Calypte costae), Broad-tailed (Selasphorus platycercus), Rufous (S. rufus), Allen's (S. sasin), Broad-billed (Cynanthus latirostris), and White-eared (Hylocharis leucotis). Calliope Hummingbirds (Selasphorus calliope) were not encountered because the men departed the mountains on 19 July, well before Calliopes typically begin passing through southern Arizona in fall migration (Phillips et al. 1964). No Anna's Hummingbirds were seen either, as they 


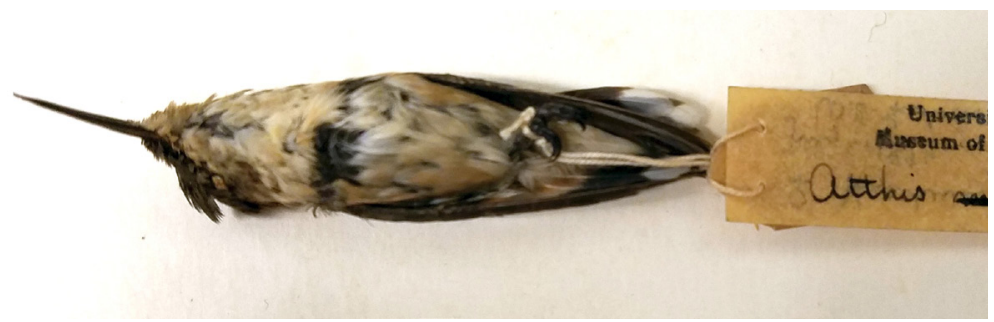

Figure 2. Immature female Bumblebee Hummingbird (Atthis heloisa) in the collection at the Museum of Vertebrate Zoology. University of California, Berkeley.

Photo courtesy of Carla Cicero

had not yet occupied southeast Arizona. The four men observed a total of about 86 bird species and collected over 400 specimens. Except for one of the two Bumblebee Hummingbirds at the Smithsonian, all other specimens are housed at California Academy of Sciences in San Francisco and at the Museum of Vertebrate Zoology in Berkeley.

\section{HARRY SWARTH'S FIELD JOURNAL}

Recently I came across Harry Swarth's hand-written 1896 Ramsey Canyon field journal in a collection of family documents. The journal contains a daily record of birds observed and collected during the five-month expedition. While examining this journal in preparation for its publication (Swarth 2018), I found entries that undoubtedly refer to the two Bumblebee Hummingbirds. He used the notation, "(?) Hummer," for unidentified female or juvenile hummingbirds, or for a hummingbird nest without an attending adult. The following verbatim journal entries made on four consecutive days describe events surrounding the Bumblebee Hummingbirds:

\section{June 29}

"Will and I stayed in camp almost all day, skinning birds, and in the afternoon walked down the cañon, after an Oriole's and a Hummer's nest. The Oriole had deserted and the Hummer nest was gone. The others returned in the afternoon after going over about the same ground [Miller Canyon] that we covered yesterday. They brought back an Arizona Junco, four Redstarts, two Red-faced Warblers, a Western House Wren, three Mexican Creepers, a Long-crested Jay, a Bluebird, a male Rivoli Hummer, a (?) Hummer, and an adult male Olive Warbler. They collected a set of Coues' Flycatchers, found several nests containing incomplete sets. They also found Bluebirds, Wren, and Robins' nests containing young."

June 30

"Will and I stayed in camp, and the others went over to Brown's Cañon, and the wash below. They shot five Vermilion Flycatchers, an Ash-throated Flycatcher, two Bridled Tits, two Baird's Wrens, a (?) Hummer, and a Shore lark. They took three sets of (?) Hummer, a set of Vermilion Flycatchers and a set of White-necked Raven."

July 1 (excerpt)

"Will and I walked down the cañon, after skinning what birds we had." 
July 2 (excerpt)

"In the morning Will went over the cliff to the Swift's nest from which Howard took the set. There were no eggs there, so he took the nest. There were no birds to be skinned so Will shot a Bridled Tit and Lead-colored Bush-tit. The others went up the right hand cañon and brought back about twenty five birds among them a male Rivoli Hummer."

Several discrepancies exist between the dates and locations on the Bumblebee Hummingbirds' museum tags and details recorded in Swarth's journal. Regarding the collection date, he wrote that on 29 and 30 June, single unknown hummingbirds [i.e., "(?) Hummer"] were brought to camp. These are the only two such unidentified hummingbirds mentioned in the entire journal. Significantly, Swarth's notes reveal that the hummingbirds were collected on two different days in late June, not on the same day as stated on the tags and in the publications that cite these records. Furthermore, according to the notes the birds were not actually prepared on 2 July. His entry for this day states, "there were no birds to be skinned." On the other hand, the journal entry for 1 July states, "Will and I walked down the cañon, after skinning what birds we had." Judson may have written 2 July on the specimen tags to mark the day he thought he had skinned the birds, although he appears to have been off by a day. Typically, the specimen tag date signifies the collecting date rather than the preparation date. I did not locate or examine any field notes from other expedition members to corroborate these details.

The journal states that one of the unknown hummingbirds was collected in Miller Canyon and the other in Brown's Canyon. Miller Canyon is similar in size to Ramsey Canyon and is about $5 \mathrm{~km}$ south, whereas Brown's Canyon is a small, shallow side canyon directly off Ramsey. Swarth (1904:19) gave Ramsey Canyon as the collecting location but indicated that the two birds were not taken together: "Atthis morcomi Ridgway. Morcom Hummingbird: Known only from two females shot by H. G. Rising, July 2, 1896. These were taken in Ramsey Canyon, not together but not far distant from one another; and at an altitude of about 7,500 feet. I have looked carefully for this species since then, but have seen nothing that I could ascribe to it, though possibly when Calliope was so abundant there might have been some of morcomi with them without my noticing."

The journal shows that the hummingbirds, therefore, were not collected in Ramsey Canyon sensu stricto, and could have been collected as far as $8 \mathrm{~km}$ from one another.

Considering the lack of any other sightings in the U.S., a question could remain: were the hummingbirds collected in Mexico? Swarth's journal does not mention contacts with anyone from Mexico during the men's stay in Ramsey Canyon, and very few visitors came to camp. For example, their only visitor from nearby Fort Huachuca was a U.S. Army photographer on 12 July. The men traveled a considerable distance from the mountains on only three occasions, to purchase supplies in Fairbank (now a ghost town) $50 \mathrm{~km}$ away. When field work ended on 19 July they boarded the train at the railroad siding north of Fort Huachuca, and headed home via Benson to Tucson on to Los Angeles. None of the men traveled across the border into Mexico. 


\section{IDENTIFICATION CONFIRMED AND EARLY PUBLICATIONS ON THE BUMBLEBEE HUMMINGBIRDS}

The group continued to puzzle over the mysterious female hummingbirds after they returned to Los Angeles. As no one in the southern California ornithological community was able to identify the specimens, the men sent them to the U.S. National Museum in Washington, D.C., where Robert Ridgway determined that they were Atthis hummingbirds and represented a species new to the United States. Ridgway also concluded that they were sufficiently distinct from Atthis heloisa to be a new species, which he named Morcom's Hummingbird (Atthis morcomi) (Ridgway 1898). This must have been an exciting conclusion to the field work and a fitting tribute to the expedition's benefactor George Morcom. Ridgway concluded his paper by stating, "This new species is dedicated to Mr. G. Frean Morcom, of Los Angeles, California, to whom I am indebted for the privilege of describing it. The type was presented to the National Museum by Mr. W. B. Judson in honor of George Morcom."

Morcom's Hummingbird had a brief lifespan as a full species. By 1914 , in A Distributional List of the Birds of Arizona, Swarth followed the consensus of others that the specimens represented a subspecies (Atthis heloisa morcomi). By 1931, following further analysis by Bangs (1927), the A.O.U. Checklist (1931) synonymized A. h. morcomi with A. heloisa. This determination, however, has not been universally accepted.

\section{THE SOURCE POPULATION OF THE RAMSEY CANYON BUMBLEBEE HUMMINGBIRDS}

If the subspecific identity of the specimens could be determined with certainty, it might be possible to identify their source population. Two subspecies of the Bumblebee Hummingbird are recognized in most recent literature (e.g., Friedmann et al. 1950, Clements et al. 2017). The northern subspecies, A. h. margarethae, occurs in the mountains of northwest Mexico from southeast Sinaloa and southwest Chihuahua to Jalisco, at an elevation of 1500 to $3000 \mathrm{~m}$ (Moore 1937, Friedmann et al. 1950). The range mapped by Arizmendi et al. (2013) extends north to about $560 \mathrm{~km}$ south of Ramsey Canyon. The southern subspecies, A. h. heloisa, occurs in the highlands of central Mexico from central Tamaulipas to Guerrero and Oaxaca (Moore 1937, Clements et al. 2017).

For his description of A. h. margarethae Moore (1937:99) examined the adult Ramsey Canyon specimen, called these birds "vagrants" (although late June seems early for vagrants), and stated, "the action of the A.O.U. Committee in relegating Atthis morcomi to the synonymy of Atthis heloisa heloisa is a logical one." Phillips et al. (1964) disagreed, maintained the Ramsey Canyon specimens within the subspecies morcomi, and asserted that $A$. $h$. margarethae was not valid. According to Phillips et al. (1964:64), "The two Arizona specimens are the types of the pale northwest-Mexican race morcomi (Ridgway), which breeds in the Sierra Madre Occidental from southern Chihuahua south." Howell (2002) inspected the specimens, considered their systematic status, and concurred with Phillips et al. Although this conclusion 
makes sense from the geographical proximity of margarethae, the population from which the 1896 birds originated appears to remain an open question.

In conclusion, Harry Swarth's field journal provides details that establish the region around Ramsey Canyon, Arizona, as the locale for the two Bumblebee Hummingbird specimens collected in 1896. The journal also reveals other pertinent facts: one bird was collected in nearby Brown's Canyon and the other in Miller Canyon, and the birds were not collected on 2 July as denoted on the museum tags, but on 29 and 30 June. Other questions still persist. Were Bumblebee Hummingbirds breeding in the Huachuca Mountains when discovered in 1896, as suggested by the presence of the immature female? If they were breeding, why were no males observed? Has the habitat in the Huachuca Mountains changed significantly over the past 122 years, making this area unsuitable today? And, finally, why is the Bumblebee Hummingbird entirely absent in the southwestern United States today?

\section{ACKNOWLEDGMENTS}

I thank Jon L. Dunn for suggesting that I summarize my grandfather's field notes to clarify details about the Ramsey Canyon records. Christopher M. Milensky, U.S. National Museum (Smithsonian Institution), and Carla Cicero, Museum of Vertebrate Zoology, provided photographs. Thanks to Gary H. Rosenberg and Steve N. G. Howell for sharing thoughts on the Bumblebee Hummingbird. An earlier draft benefited from constructive comments by Christopher J. Clark, Marilyn L. Fogel, Daniel D. Gibson, and Gary R. Graves.

\section{LITERATURE CITED}

American Ornithologists' Union. 1910. Check-list of North American Birds, 3rd ed. Am. Ornithol. Union, Washington, D.C.

Arizmendi, M. del C., Rodríguez-Flores, C. I., Soberanes-González, C. A., and Schulenberg, T. S. 2013. Bumblebee Hummingbird (Atthis heloisa), version 1.0, in Neotropical Birds Online (T. S. Schulenberg, ed.). Cornell Lab Ornithol., Ithaca, NY; https://doi.org/10.2173/nb.bumhum.01.

Bangs, O. 1927. Atthis heloisa morcomi Ridgway, not a valid subspecies. Condor 29:118-119.

Clements, J. F., Schulenberg, T. S., Iliff, M. J., Roberson, D., Fredericks, T. A., Sullivan, B. L., and Wood, C. L. 2017. The eBird/Clements Checklist of Birds of the World: version 2017; www.birds.cornell.edu/clementschecklist/download/.

Dunn, J. L., and Alderfer, J. 2017. A Field Guide to the Birds of North America, $7^{\text {th }}$ ed. Natl. Geogr. Soc., Washington, D.C.

Friedmann, H., Griscom, L., and Moore, R.T. 1950. Distributional checklist of the birds of Mexico, part 1. Pac. Coast Avifauna 29.

Howell, S. N. G. 2002. Hummingbirds of North America: The Photographic Guide. Academic Press, San Diego.

Howell, S. N. G., and Webb, S. 1995. A Guide to the Birds of Mexico and Northern Central America. Oxford Univ. Press, Oxford, England.

Merriam, C. H. 1890. Results of a biological survey of the San Francisco Mountain region and desert of the Little Colorado in Arizona. N. Am. Fauna 3:1-136.

Moore, R. T. 1937. Four new birds from northwestern Mexico. Proc. Biol. Soc. Washington 50:95-102.

Phillips, A., Marshall, J., and Monson, G. 1964. The Birds of Arizona. Univ. Ariz. Press, Tucson. 
Ridgway, R. 1898. Description of a new species of hummingbird from Arizona. Auk 15:325-326.

Swarth, C. W. 2018. An Expedition to Ramsey Canyon: The 1896 Field Journal of Ornithologist Harry S. Swarth. Yaqui Gulch Press, Mariposa, CA.

Swarth, H. S. 1904. The birds of the Huachuca Mountains, Arizona. Pac. Coast Avifauna 4.

Swarth, H. S. 1914. A distributional list of the birds of Arizona. Pac. Coast Avifauna 10. Zyskowski, K., Peterson, A. T., and Kluza, D. A. 1998. Courtship behaviour, vocalizations, and species limits in Atthis hummingbirds. Bull. Br. Ornithol. Club 118:82-90.

Accepted 20 September 2018 